\title{
Design of Tourist Souvenirs Injected into Lushan Poetry Culture
}

\author{
Wei Wu
}

\author{
Suan Sunandha Rajabhat University \\ *27164369@qq.com
}

\begin{abstract}
Firstly, this paper analyzes the present situation of Lushan tourist souvenirs, and elaborates the specific application of Lushan poetry in the design of Lushan tourist souvenirs, including the application of Lushan poetry in the font creation of tourist souvenirs and the application of Lushan poetry in the design process of tourist souvenirs. Then it specifically analyzes the role of Lushan poetry in the design of Lushan tourist souvenirs, including the application of Lushan poetry is conducive to promoting the sales of tourist souvenirs, the application of Lushan poetry is conducive to enhancing the cultural connotation of souvenirs and the application of Lushan poetry effectively promotes the innovation of tourist souvenirs. Therefore, they can't be the same, and they need to be valued and developed.
\end{abstract}

\section{Keywords: Lushan Mountain, Poetry Culture, Tourist Souvenirs, Design}

\section{INTRODUCTION}

Lushan Mountain has distinctive regional cultural characteristics in Chinese history, so there are many ancient poems on this theme. For example, "Why can't I tell the true shape of Lushan? Because I myself am in the mountain" and so on. Since ancient times, Lushan poetry culture has been continuously inherited and developed, which makes more people know and understand Lushan from poetry culture, and the influence of Lushan poetry culture is also constantly expanding. Compared with other regions, the cultural and spiritual connotation of Lushan's poems is more special. Lushan has been loved by scholars in the past dynasties, and more and more poems have been written on this topic, and the cultural connotation of Lushan has become more and more thick. Lushan poetry has been expanded due to the rich collective activities of literati in Lushan, which also makes the poetry culture cover more contents and broaden the channels of poetry culture. With the constant change of rulers, Lushan Mountain is valued by more rulers, and the poetry culture of Lushan Mountain is also expanded in the change of political center. With the continuous development of Lushan tourism, more tourist souvenirs related to Lushan culture have been derived. However, the design of tourist souvenirs is little different from those in other regions, and the Lushan poetry culture has not been well spread through tourist souvenirs, and there is still a big gap in products around cultural tourism. The inheritance and development of Lushan culture, with tourist souvenirs as the carrier of communication, also restricts the communication and development of Lushan poetry culture. The sales volume of Lushan tourist souvenirs is closely related to the integration of Lushan poetry culture in the design of tourist souvenirs. The popularity and familiarity of Lushan mountain by the public all originate from Lushan poetry culture, so it is urgent to integrate Lushan poetry culture into the design and creation of tourist souvenirs. Tourist souvenirs need to carry the local culture, poetry culture and customs, so that the audience can feel the local customs, poetry culture and other unique cultural customs through souvenirs. At the same time, through the spread of tourist souvenirs, the spread of poetry culture can be expanded, which is conducive to the inheritance and development of Lushan poetry culture.

\section{PRESENT SITUATION OF LUSHAN TOURIST SOUVENIRS}

At present, Lushan tourism is gradually recognized by more people, and tourist souvenirs are also derived, but the sales volume of tourist souvenirs is not very impressive. In recent years, cultural and creative products related to tourist souvenirs have attracted wide attention from all walks of life, such as peripheral products related to the Palace Museum, hand-made 
lipstick ornaments and so on, which set off a buying upsurge of cultural and creative products around tourism. It also makes tourist cities all over the country compete for effectiveness, and the development and sales of tourist souvenirs are also valued by tourist attractions. Tourism souvenir-related industries show a good development trend, but overall, the development level of Lushan tourism souvenir is in the middle and lower position. Lushan poetry culture assists the design of Lushan tourist souvenirs, which is the focus of Lushan tourism at present. At the same time, combining modern design industry with traditional culture of Lushan poetry culture will help to increase the cultural characteristics of tourist souvenirs[1].

Compared with other local cultural resources, Lushan Mountain is still in the initial stage of development, the design and sales of tourist souvenirs have not entered the regular track, the formation of tourism product development chain has also been hindered to some extent, and it has not been able to effectively use Lushan Mountain poetry culture to promote the sales of tourist souvenirs. Since the inheritance and development of Lushan poetry culture, its culture is profound, distinctive and rich in content. However, compared with the cultural and creative products of other tourist cities, the poetry culture is too rigid and limited, and its sense of modernity and design is relatively weak. Tourist souvenirs are also a kind of cultural and creative products, so tourist souvenirs are the same as other cultural products in culture and technology. Most tourist souvenirs are still in the stage of imitating other cultural and creative products in culture and design, and do not have their own distinctive features, which makes the designed tourist souvenirs completely out of touch with the modern living atmosphere of the audience, and the product forms are not easily recognized by the audience. The design of tourist souvenirs can't only pay attention to the decorative memorial, but also the practicality is one of the issues that need to be considered in the design of tourist products. The design of tourist souvenirs needs to make the products have a sense of design and practicality, make the products have a certain vitality, promote the inheritance of traditional culture, and at the same time be recognized by the audience, so that after purchasing, the audience can not only put them on hold as ornaments, but also actually use them.

Foreign tourists don't have enough in-depth knowledge of Lushan's regional culture by traveling and buying souvenirs. At the same time, tourism-related employees don't transmit the value of Lushan's cultural connotation, which is an important reason that restricts the development of tourist souvenirs. At present, tourists are still the main service objects of tourist souvenirs, and the consumer groups of tourist souvenirs have not been expanded, which makes the design of tourist souvenirs also focus on tourists. It is a small part of the tourist souvenir audience, and it can't well promote the development of tourist souvenirs and related peripheral cultural creations, and it is still a continuation without innovation. The existing tourist souvenirs of Lushan Mountain are basically gifts, which can only attract a small number of tourists to buy, and have no attraction to local customers. The audience of tourist souvenirs is not just tourists, but all consumers, including local customers. At present, the tourism and cultural resources of Lushan Mountain need to be developed and updated, and the tourist souvenirs of Lushan Mountain can also be called the business cards of Lushan Mountain[2]. Intangible assets accumulated in the process of historical progress and development are one of the components of regional culture, and the integration and development of tourism economy and regional culture is also one of the key issues that the local tourism industry needs to pay attention to. After being fully integrated, it will form brand culture and effectively promote the development of the tourism industry.

\section{THE SPECIFIC APPLICATION OF LUSHAN POETRY IN THE DESIGN OF LUSHAN TOURIST SOUVENIRS}

\subsection{The Application of Lushan Poetry in the Font Creation of Tourist Souvenirs}

The fonts and graphics of Lushan tourist souvenirs are integrated into Lushan poetry culture, with landscape scenes as the skeleton and official script fonts as the skeleton. Then, the design patterns related to Lushan culture are used as the finishing touch to enhance the cultural connotation of this tourist souvenir and give consumers a visual impact. The auxiliary patterns and graphics related to Lushan culture are used to design tourist souvenirs, which makes the cultural and creative products more meaningful and novel in shape[3].

\subsection{The Application of Lushan Poetry in the Design Process of Tourist Souvenirs}

In the design of tourist souvenirs of Lushan Mountain, the characteristic scenery of Lushan Mountain is combined with font design and the poetry culture of Lushan Mountain runs through the whole design process. The overlapping layers of Lushan Mountain can embody the image in the design of tourist souvenirs, and the overlapping peaks can be used as cultural elements in the design of tourist souvenirs. Tourist souvenirs should be both cultural and practical, the essence of culture, which needs to be reflected in the design. The design of tourist souvenirs combined with Lushan poetry culture can enhance the cultural connotation and added value of souvenirs, and at the 
same time, in this process, the classics of Lushan poetry culture can be passed down and the local culture of Lushan can be promoted[4].

\section{THE FUNCTION OF LUSHAN POETRY IN THE DESIGN OF LUSHAN TOURIST SOUVENIR}

\subsection{The Application of Lushan Poetry is Conducive to Improving the Sales Volume of Tourist Souvenirs}

In the design of Lushan tourist souvenirs, the auxiliary design of Lushan poetry culture can promote the sales of tourist souvenirs to a certain extent. With the improvement of people's cognition and reality, the traditional forms of tourist souvenirs can no longer meet the needs of consumers, and tourist souvenirs all over the country are the same, and the forms are single and boring. Lushan tourist souvenirs also stick to this, which leads to less sales of tourist souvenirs. Lushan poetry is not only the carrier of Lushan culture, but also an effective way to spread the connotation of Lushan culture. Lushan Mountain has distinctive regional characteristics, and its poetry culture spreads widely. The integration of Lushan Mountain poetry culture into the design of tourist souvenirs can increase the function of cultural communication on the basis of the original commemorative significance, and invisibly attract consumers more. Not only the tourist audience can buy it, but also the consumers in online network channels will have a desire to buy it.

\subsection{The Application of Lushan Poetry is Conducive to Enhancing the Cultural Connotation of Souvenirs}

Lushan Mountain has beautiful scenery, many scenic spots and rich cultural elements. In the design process of tourist souvenirs, Ruqin Lake and the pine greeting guests are selected as design elements, which are design "elements" with great Lushan cultural characteristics and visual effects. Ruqin Lake in Lushan Scenic Area is one of the famous scenic spots. It is a street park. It is located in Guling Town, Lushan City. The whole lake of the name is like a violin, which is particularly romantic and artistic. Lushan tourist souvenirs will be extracted from the pavilion in the center of the lake like Qin Lake as a design element, and the surrounding complex environment will be removed. At the same time, the details will be simplified and refined as a cultural element of Lushan Mountain[5]. In the process of design, the elements are processed and refined to form a brand-new form, and the features of the elements are retained while innovation is carried out, so that the tourist souvenirs obtained are fresh in features and the cultural connotation is improved.

\subsection{The Application of Lushan Poetry Effectively Promotes the Innovation of Tourist Souvenirs}

Most of the traditional tourist souvenirs are fans, ornaments, paintings and so on, and the types of souvenirs are relatively single. The application of Lushan poetry culture can promote the innovation of Lushan tourist souvenirs. In the process of designing tourist souvenirs of Lushan poetry culture, it is necessary to make use of modern color collocation to collide with traditional poetry culture, so that the inheritance degree of Lushan culture is expanded, and at the same time, it can also promote the economic development of Lushan area[6]. Lushan poetry theme cultural tourism souvenirs need to be practical and portable, which can promote the desire to buy. In the design and production of tourism cultural and creative products, we should use modern technology to design cultural and creative tourist souvenirs with both connotation and characteristics. We should pay attention to the choice of design vectors that must meet the needs of the audience and have high cost performance.

\section{LUSHAN POETRY CULTURE FURTHER PROMOTES THE CREATIVE CONCEPTION OF TOURIST SOUVENIRS}

\subsection{Tourist Souvenirs are More Fashionable and Younger}

The creative conception of tourist souvenirs needs to break the traditional shackles. The integration of Lushan poetry culture can make souvenirs more fashionable and younger. Using abstract graphics to endow Lushan Mountain in Lushan poetry culture with a new image, through the combination of font graphics and poetry, tourist souvenirs can be more modern and contemporary, and easily liked by young social groups. Lushan poetry culture broadens the creative conception of tourist souvenirs, which makes tourist souvenirs more fashionable and younger, distinctive Lushan cultural characteristics of tourist souvenirs, richer font elements of tourist souvenirs, sublimated value connotation of tourist souvenirs and more creative[7]..

\subsection{Tourist Souvenirs Have Distinctive Lushan Cultural Characteristics}

With the development and progress of information technology, people's lifestyle and thinking have gradually changed. Now design elements are more important in the design of various products, and the design of tourist souvenirs is no exception. Tourist souvenirs are "business cards" that show the local scenery and cultural connotations. They should not be too old-fashioned and should be created by combining 
poetry culture. The design concept should also be innovative. They should be designed with divergent creative thinking, and the description of Lushan Mountain in poetry culture should be used to create souvenirs for the purpose of spreading culture and encouraging consumption[8].

\subsection{Tourist Souvenirs are More Rich in Font Elements}

In the creation of tourist souvenirs, font elements are one of the important components. Too monotonous fonts can't arouse consumers' desire to buy. The characteristic scenery of Lushan Mountain and the poetry culture of Lushan Mountain can be combined with the font design. In the font design of the cover of tourist souvenirs, arranging and combining the title font and the text font can improve the integrity of souvenirs. Unique font elements can enhance the recognition of tourist souvenirs, improve the economic benefits and market recognition of tourist souvenirs, and further play the role of cultural inheritance[9].

\subsection{The Value Connotation of Tourist Souvenirs is Sublimated}

The value of tourist souvenirs has never brought much economic benefits. Economic benefits are only a part of its value. Its more important value is to spread local culture and show folk customs. The design of Lushan tourist souvenirs can further sublimate the value connotation of souvenirs due to the integration of Lushan poetry culture. While promoting tourism and improving economic benefits, souvenirs are endowed with new connotations, which makes them seem to have "life", flesh and blood and emotion, and tourist souvenirs become more valuable.

\subsection{Tourist Souvenirs are More Creative}

Most of Lushan poetry culture only exists in the cover design and product packaging of tourist souvenirs. With the development of information technology, fashionable and young cultural and creative products are more likely to be liked by consumers. In the font design and landscape elements of Lushan Mountain, Lushan poetry culture is also integrated into it. For example, in souvenirs such as Qinhu Lake and Lushan welcoming pine, the design of souvenirs is not only to carry them in the design, but also to analyze them, combine poetry culture with the actual landscape, and then use the construction of lines and graphics to make tourist souvenirs more creative[10].

\section{CONCLUSION}

At present, because the development of cultural resources does not fully meet the market demand, the integration and docking of cultural industry and tourism industry has not achieved the expected results. There are still many problems to be solved in the design and marketing of Lushan tourist souvenirs. With the assistance of modern technology and the integration of poetry culture, the design of Lushan tourist souvenirs will be gradually improved. In the process of designing and creating tourist souvenirs, tourists, local and internet channel customers should be considered at the same time. Only in this way can tourist souvenirs create more commercial value, and also can tourist souvenirs develop continuously and make progress. The government can also provide some innovative support and incentive policies to guide the development of local tourism culture with clear guidance, promote the sales of tourist souvenirs and promote the spread of poetry culture.

\section{ACKNOWLEDGMENTS}

I deeply appreciate Asst. Prof. Dr. Pisit Puntien of Suan Sunandha Rajabhat University for his guidance and encouragement to this paper.

\section{REFERENCES}

[1] Liu Fenghua.Discussion on the Construction of Lushan Tea Garden Project in Cultural Tourism Industry-University-Research[J].Tea In Fujian, 2021,43(11):71-72.

[2] $\mathrm{Fu}$ Jie.The Connotation of "Humanistic Holy Mountain" in Lushan Mountain and the Fusion Path of Cultural Tourism[J].Tourism Today,2021, 19(29):19-21.

[3] Liu Xueling, Ma Qiufang.Spatial Behavior Analysis of Lushan Tourist Scenic Spot Based on Network Text[J].Journal Of Tongren University, 2021,23(05):84-91+100.

[4] Li Jinling.Inherit the Traditional Culture, and Make the Teaching of Ancient Poetry More Focused[J]. Read-write arithmetic,2021(28):189-190.

[5] Wang Mengyao.Tourism Souvenir Design Injected into Lushan Poetry Culture[J].Today \& ancient Chinese creation,2020(46):37-38.

[6] $\mathrm{Su}$ Yixuan, Liu Chunqing.Characteristics and Changes of Lushan Cultural Landscape-—Based on the Text Analysis of Ancient Poetry[J].Cultural Relics in Southern China,2020(04):282-289.

[7] $\mathrm{Hu}$ Wei, Li Mingyan.Lushan Museum: The "Museum Group" Highlights the Cultural Charm of Lushan Mountain[J].Cultural Monthly,2020(08): 84-85. 
[8] Peng Congping.Study on Lushan Tourism Culture Image Design in Jiangxi Province[D].Jiangxi Science and Technology Normal University,2018.

[9] Dong Chuifeng.Research on the Design of Lushan Tourist Product[D].Jiangxi Normal University, 2013.

[10] Cheng Sheng.Based on the Characteristics of Lushan Tourist Souvenirs Design Research[D]. Nanchang University, 2015. 